\title{
Comparative study of urban development and groundwater condition in coastal areas of Buenos Aires, Argentina
}

\author{
Leandro Rodrigues Capítulo $^{1} \cdot$ Silvina C. Carretero $^{1} \cdot$ Eduardo E. Kruse $^{1}$
}

Received: 4 July 2016 / Accepted: 20 January 2017 /Published online: 8 February 2017

(C) Springer-Verlag Berlin Heidelberg 2017

\begin{abstract}
The geomorphological evolution of a sand-dune barrier in Buenos Aires, Argentina, is analyzed as a factor regulating the fresh groundwater reserves available. The impact of geomorphological evolution and the consequences for the social and economic development of two coastal areas are assessed. This is one of the most important tourist destinations in the country; for study purposes, it was divided into a northern sector and a southern sector. In the southern sector, the exploitable groundwater is associated with the Holocene and upper Pleistocene geomorphological evolution, which generated three interrelated aquifer units, constituting a system whose useful thickness reaches at least $45 \mathrm{~m}$. In contrast, the northern sector is restricted to two Holocene aquifer units, whose total thickness is on the order of $12 \mathrm{~m}$. The morphological characteristics and the occurrence of the largest fresh groundwater reserves in the southern sector are indicators of better conditions for economic growth, which is mainly reflected on the expansion of real estate ventures. The relationships of transmissivity vs area of real estate ventures (Arev), and total water consumption vs Arev, are indicators for the sustainable management of the water resources. The approach chosen may be used by decision makers in other regions to assess the feasibility of future tourism projects on
\end{abstract}

Eduardo E. Kruse

kruse@ fcnym.unlp.edu.ar

Leandro Rodrigues Capítulo

leandrorodriguescapitulo@gmail.com

Silvina C. Carretero

scarretero@fcnym.unlp.edu.ar

1 Consejo Nacional de Investigaciones Científicas y Técnicas (CONICET). Facultad de Ciencias Naturales y Museo, Universidad Nacional de La Plata (UNLP), 64 No. 3, 1900 La Plata, Argentina the basis of the availability of water resources associated with geomorphological features.

Keywords Coastal aquifers · Groundwater monitoring · Socio-economic aspects $\cdot$ Tourism $\cdot$ Argentina

\section{Introduction}

Hydrological systems constitute an interface between the environment and human needs regarding water consumption. Hydrological knowledge is essential in planning for the sustainable use of water resources, and for the exploitation and management of the water supply for sewage treatment, food, energy production and social development (Montanari et al. 2013).

Hydrogeologists should not avoid considering the implications of the social management of their research. The adoption of a more integrated approach, combining hydrogeology and socio-economic development, facilitates the evaluation of the relationship between groundwater and society, which necessarily implies considering not only how human activities may affect groundwater, but also how groundwater affects human activities. These conditions lead to the definition of the concept of socio-hydrogeology $(\operatorname{Re} 2015)$ as a means to introduce the social dimension in hydrogeological research.

Understanding the sociopolitical and cultural economies that surround groundwater and the management tools that may be used is as important as understanding the physical system. The engagement between the physical and socioeconomic media is key to interpreting the resource use patterns and management options (Burke and Moench 2000).

Tourism is one of the fastest developing economies worldwide and one of the social and economic activities of relevance in many regions. Coastal areas concentrate the largest 
quantities of tourist sites and visitors. Water shortage represents a restriction for this industry: without water resources, activities involving swimming pools, golf courses, water parks, gardens, spas, and sports complexes, for example, would be impracticable (Gössling 2006; Kent et al. 2002). There are very few studies integrating coastal geomorphology and tourism activities, and they usually refer to beach morphodynamics, without taking groundwater into consideration (El Mrini et al. 2012a, b).

On occasion, coastal aquifers are small in magnitude, but they become meaningful when they meet human needs, ranging from those of urbanization to irrigation (Custodio 2010). In South America, the aquifers with greater barrier development are on the Atlantic margin and, in general, contain good quality water (da Cunha Rebouças 1999), but they are vulnerable to climate change, sea-level rise and saltwater intrusion (Carretero et al. 2013a; Koerth et al. 2014).

In Argentina, the evolution of coastal barriers in the Province of Buenos Aires has been studied from the point of view of vegetation (Monserrat 2010; Monserrat and Bonardi 2012), without including the subject of groundwater and how it relates to dunes. There are local coastal studies of the eastern coast of the Province of Buenos Aires covering the geomorphology, land use and erosion (Marcomini and López 2010), but they do not include the water resources. The temporal evolution of the sand-dune barrier and its relationship with the water resources have also been analyzed, studying the changes in recharge possibilities of the coastal aquifer (Carretero and Kruse 2014; Carretero et al. 2014), as well as its hydrochemistry (Carretero et al. 2013b; Carretero and Kruse 2015). Thus far, none of the contributions mentioned in the preceding has related the hydrogeomorphological characteristics of the coast of Buenos Aires with indicators of social and economic development related to tourism.

In this work, the hydrogeological context associated with the geomorphological evolution of the sand-dune barrier is analyzed as a factor regulating the fresh groundwater reserves available. The impact and consequences of such an evolution on the social and economic development of two coastal areas is also assessed. No research of this kind has been carried out in the region, and a comprehensive study of the aforementioned characteristics may be of interest to the authorities responsible for the coastal area.

\section{Study area}

The study area consists of the sandy coast of the Province of Buenos Aires, Argentina, which from a geopolitical viewpoint includes the districts of Partido de La Costa (northern sector) and the Partido de Pinamar (southern sector; Fig. 1). This is one of the most important tourist destinations in the country. The main economic activity is tourism; there are no industries, livestock farming, agriculture or other relevant activities, which is why water use is considered to be exclusive for human and recreational consumption. The population, which depends entirely on the coastal aquifer for water supply, increases significantly during the summer.

On the sandy coast of the Province of Buenos Aires, the typical vegetation is of a grassland type, but since the midtwentieth century there are sectors that have been artificially afforested with conifers, which constitute a tourist attraction (Rodrigues Capítulo and Kruse 2011; Rodrigues Capítulo 2015).

The climate is humid temperate, with a season with lower precipitation in the cold months (April-September) and a wet season during the warm months (October-March). The mean annual precipitation ranges between 900 and $1,000 \mathrm{~mm}$, with $60 \%$ occurring during the months with higher evapotranspiration (warm months), which is why the highest recharge rates are registered during the cold season (Carretero and Kruse 2012).

Most localities in the northern sector have no drinkingwater supply system and the population is supplied by means of individual domestic wells with no water treatment. A small percentage of inhabitants are connected to a water supply network, among them the town of San Clemente del Tuyú. The resource is extracted from a pumping field located out of the urban area using the well point system. There is a water treatment plant in which the water extracted is treated (Fe and $\mathrm{Mn}$ removal) before its distribution. In the case of the southern sector, the supply system is fed by a network of conventional wells located in the towns of Pinamar, Ostende and Valeria del Mar, which, in turn, feed a unified network. The methodology used generates, at a local level, depletion cones or drawdown areas that can be recognized in the fluctuations of the water tables and the evolution of the groundwater flow maps.

In the past 40 years, there has been a constant population increase, with different growth rates depending on the sector (Table 1). Population density is higher in the southern sector (Partido de Pinamar, with 390 people per $\mathrm{km}^{2}$ ) than in the northern one (Partido de La Costa, with 280 people per $\mathrm{km}^{2}$ ), with a total of 25,728 inhabitants in the former and 69,633 in the latter (INDEC and de la República Argentina 2010). It should be noted that, for the 1991-2001 period, in the southern sector the increase was of over $100 \%$.

The tourism occurring in the summer season, especially in January and February, causes the population to increase over ten times compared to the permanent population in the region. In the northern sector, the influx of tourists may be in excess of $2,700,000$ inhabitants in its $249 \mathrm{~km}^{2}$ area, whereas in the southern sector, 1,000,000 inhabitants in a $66 \mathrm{~km}^{2}$ area.

Regarding the employment status of visitors, they are mainly active employees, with a larger percentage in the southern sector (Partido de Pinamar). The difference is that, in the northern sector (Partido de La Costa), there are a higher percentage 
Fig. 1 Satellite image of the study area. $R P 11$ and $R P 74$ are provincial routes

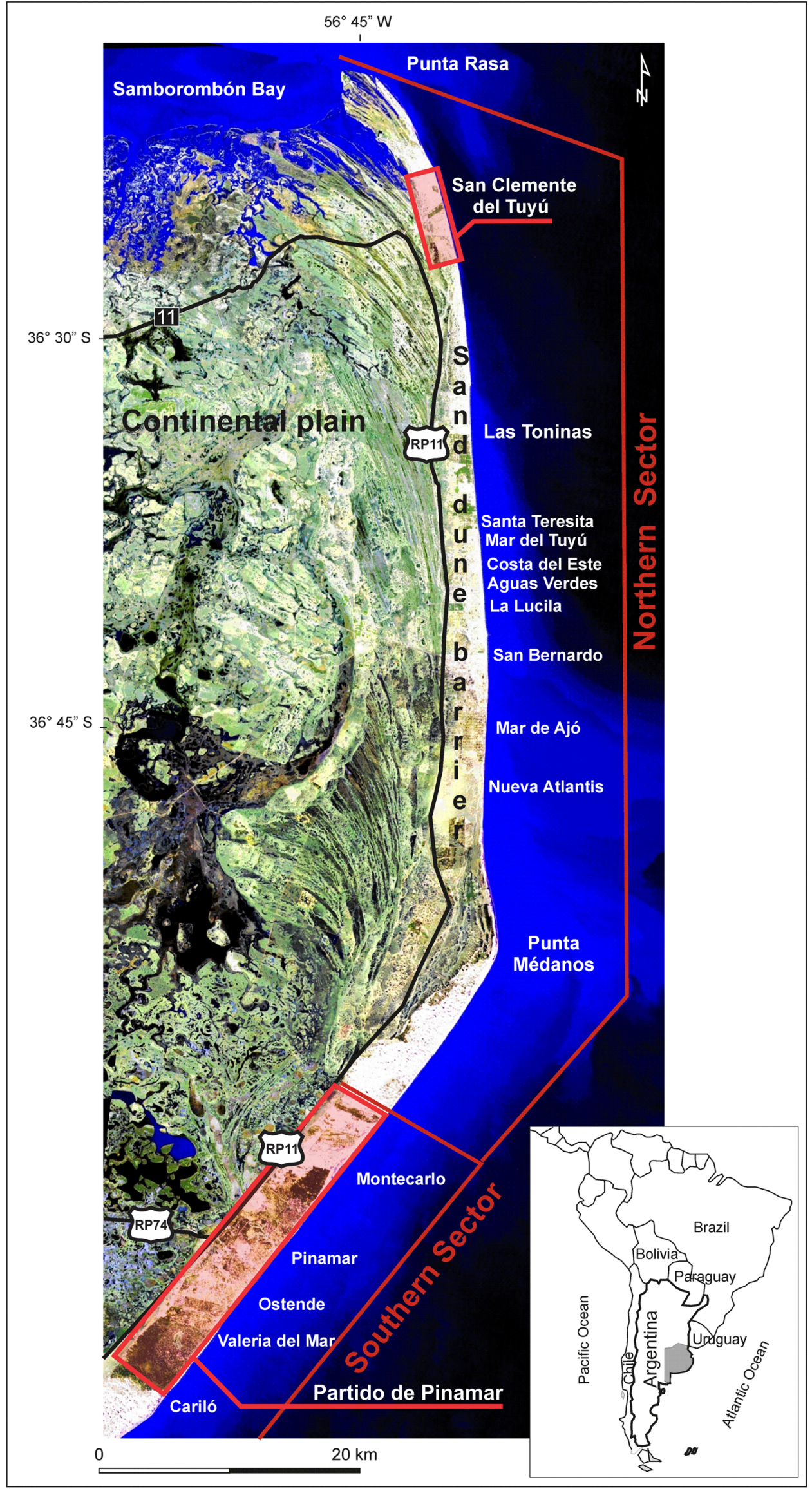


Table 1 Number of inhabitants and growth rate for the districts of Partido de La Costa (northern sector) and Partido de Pinamar (southern sector), illustrated with selected years/ranges

\begin{tabular}{|c|c|c|c|c|c|c|c|}
\hline & \multicolumn{4}{|c|}{ Population } & \multicolumn{3}{|c|}{ Growth rate $(\%)$} \\
\hline & 1980 & 1991 & 2001 & 2010 & 1980-1991 & 1991-2001 & 2001-2010 \\
\hline Partido de La Costa & 25,652 & 38,603 & 60,483 & 69,633 & 50.49 & 56.68 & 15.13 \\
\hline Partido de Pinamar & 8850 & 10,316 & 20,666 & 25,729 & 16.56 & 100.33 & 24.5 \\
\hline
\end{tabular}

of pensioners, resulting in a lower number of employed visitors than in the Partido de Pinamar, which implies lower purchasing power and fewer investment possibilities in the region. Although in both cases the largest percentages (30-36\%) of tourists have average incomes, in the case of the southern sector, $20 \%$ correspond to a high-income segment, this being the most relevant difference with the northern sector.

In both sectors, most of the tourists stay for 15 days at the destination, but in the southern sector the percentage is higher $(47 \%)$ than in the northern sector $(23 \%)$, whereby 1-week stays follow, with $25 \%$ of the visitors choosing such a length for their holidays. It should be noted that, in the southern sector, $10 \%$ stay longer than 1 month, whereas in the northern sector such length of stay is lower than $5 \%$.

In the southern sector (Partido de Pinamar), the main tourist attractions are the conifer forests, which cover more than half of the total area. This type of tree cover gives the sector a distinctive landscape, which allows the combination of local elements with those that are typical of other geographical regions, thus representing an additional attraction as regards the real estate and construction sectors.

Generally, beaches in the northern sector are wide and plain, extending between 100 and $150 \mathrm{~m}$ in width. In some localities, this landscape is being affected by erosional processes, leading to its decrease together with that of the active dune field, which has had an impact on beach activities. The sector between Nueva Atlantis and Punta Médanos stands out, as it has beaches that are practically unexplored. The northern sector is not characterized by a large forest area, but there are two golf clubs, one in Santa Teresita with a 54-ha parcel of land with lush vegetation, and another one located in Punta Médanos.

\section{Materials and methods}

\section{Hydrogeological survey}

Boreholes with depths between 10 and $40 \mathrm{~m}$ were drilled, covering the entire thickness of the aquifer in the northern and southern sectors of the study area. Auger and rotary drilling systems for drilling mud were used. The drill cutting sampling was carried out by means of sieves, followed by a mesoscopic description of the field, and a mineralogical and granulometric analysis under a stereo microscope. The carbonate fraction was determined by effervescence with hydrochloric acid. The qualitative and percentage descriptions of the mineral components of the sediments were undertaken by statistical selection. This data allowed the definition of a lithological profile for the different sedimentary environments. A palaeoenvironmental reconstruction was made, and the interpretations were validated with reference literature on the region, such as Parker and Violante (1989), Parker (1991), Violante et al. (2001) and Cavallotto (2002), among the most important.

In the southern sector, deeper monitoring wells were drilled (>40 m) near the coastline, in order to assess the behaviour of the area of the freshwater-saltwater interface. Electrical conductivity profiles were measured using a Solinst meter (model TLC 107). The same instrument was also used to detect the presence or absence of chemical zonation in the rest of the wells.

Hydrofacies were assigned according to the hydraulic behaviour of the lithostratigraphic units identified. A hydrofacies is a homogeneous sedimentary unit that, having developed under specific conditions, leads to a specific hydrogeological behaviour (Anderson 1989). The hydraulic characterization of the aquifer layers was carried out by means of constant flow rate pumping tests, using the methods by Theis (1935), Hantush and Jacob (1955) and Neuman (1975), which made it possible to obtain the hydraulic parameters of the aquifer: transmissivity $(T)$, hydraulic conductivity $(K)$, specific yield (Sy), vertical transmissivity $\left(T_{v}\right)$ and vertical hydraulic conductivity $\left(K_{v}\right)$.

Water balances were estimated by the Thornthwaite and Mather (1955) and Penman-Monteith (Allen et al. 1998) methods, differentiating the forested and non-forested dune in order to establish mean excess values for each of them. The data used correspond to the Pinamar and Villa Gesell stations of the Servicio Meteorológico Nacional (National Weather Service, SMN).

The analysis of the water resources focuses on the sites in which the wells of the groundwater monitoring network are established (San Clemente del Tuyú, Las Toninas, Santa Teresita and Partido de Pinamar). This network has, on average, two wells per $\mathrm{km}^{2}$. The regional and local hydrogeological system was described on the basis of water-table contour maps, calculating average hydraulic gradients, and the freshwater reserves available per area unit.

Major cations and anions were among the chemical determinations made, while in situ measurements of the $\mathrm{pH}$ and electrical conductivity values were carried out by means of a multiparameter water quality meter and a conductivity meter, 
respectively. Total dissolved solids were determined gravimetrically (SM-2540 B). The following methods were used to analyze major cations: EDTA Titrimetric SM-3500-Ca B (calcium); Flame Emission Photometric Method SM-3500-Na B (sodium); Flame Emission Photometric Method SM-3500-K B (potassium); and Calculation Method SM-3500-Mg B (magnesium). The major anions were determined by the following methods: Titrimetric SM-2320 B (bicarbonate); Nephelometric SM-4500-SO - -E (sulphate); and Mohr SM4500- $\mathrm{Cl}$ (chloride). As regards the nitrogen compounds, they were detected by the following: Ion-selective Electrode SM$4500-\mathrm{NO}_{3}{ }^{-} \mathrm{D}$ (nitrate); Ilosvay von llosva SM-4500 $\mathrm{NO}_{2}{ }^{-}$ adaptation (nitrite); Ion-selective Electrode SM-4500- $\mathrm{NH}_{3}-\mathrm{D}$ (ammonia). The analysis of total iron was carried out by the SM-3500-Fe B Colorimetric Method, and in the case of manganese, by the SM-3500-Mn and B Persulphate methods.

Oxygen-18 $\left(\delta^{18} \mathrm{O}\right)$ and deuterium $\left(\delta^{2} \mathrm{H}\right)$ isotopes were determined. The isotopic analyses were carried out by the Instituto de Geocronología y Geología Isotópica (INGEIS, Geochronology and Isotope Geology Institute) of the Consejo Nacional de Investigaciones Científicas y Técnicas (CONICET, National Scientific and Technical Research Council) and the Universidad de Buenos Aires (UBA, University of Buenos Aires), Argentina. Samples were treated following conventional techniques and measured using highprecision laser spectroscopy, i.e. off-axis integrated cavity output spectroscopy.

\section{Population and groundwater consumption}

The evolution of the population was analyzed based on the statistics published by the INDEC and de la República Argentina (2010). The information obtained from the analysis of the surveys undertaken in both districts helped define the similarities and differences of the most important economic activities in the region (Secretaría de Turismo, Cultura y Educación, Municipalidad de Pinamar 2015a; Secretaría de Turismo, Deportes y Cultura, Municipalidad de La Costa 2015b). Information was obtained as regards the presence of real estate ventures (ARBA 2015) and the surface area that each represents, in order to establish the relevance of this economic activity.

The relationship between $T$ in each sector and the area covered by the real estate ventures (Arev) was assessed. The total water consumption (TWC) of the ventures was estimated considering the projected population for each, assuming an average consumption of $200 \mathrm{~L} / \mathrm{d}$ (Planas et al. 2000). The values for irrigation water, which are not low in real estate ventures, were estimated following Domene and Sauri (2006), and Hof and Schmitt (2011). These authors state that the water volume for garden irrigation ranges between 40 and $50 \%$ of the indoor consumption. Ventures with golf courses show an extra consumption, higher than $500 \mathrm{~m}^{3} / \mathrm{d}$. A generalization was made based on Durán Valsero et al. (2001) and Lyman (2012), who calculated an average irrigation value for the standard area of an 18-hole golf course. In order to compare the results obtained, data on area and consumption by coastal tourism ventures in Spain (Majorca; Hof and Schmitt 2011) and Malaysia (Langkawi and Miri; Tang 2012) were requested.

\section{Results}

\section{Geomorphological and hydrogeological setting}

The sand-dune barrier extends between Punta Rasa, to the north, and Mar Chiquita, to the south, with a width that varies between 2 and $4 \mathrm{~km}$. It borders to the west with the continental plain, which is characterized by elevations of less than $2 \mathrm{~m}$ above sea level (a.s.l.) and the predominance of clayey and silty materials, with southeast-northwest-trending gullies that drain towards the Samborombón Bay.

The sand dunes in the barrier are low (elevations between 2 and $11 \mathrm{~m}$ a.s.l.; Fig. 2a) and fixed by scant vegetation in the northern sector, whereas in the area of Punta Médanos and in the Partido de Pinamar they reach maximum elevations, ranging between 28 and $36 \mathrm{~m}$ a.s.1. (Fig. 2b). In this environment, the soils are sandy, show no horizon development, and are excessively drained and unstable, which makes them almost completely unfit for agricultural and livestock farming activities.

The lithological variations in the units recognized in the subsurface for each sector are shown in Fig. 3. In these type sections, the difference between the lithological units of the northern and southern sectors can be observed. The former is a sand unit (approximately $10 \mathrm{~m}$ thick) that overlies a clay layer, while on the other hand, in the southern sector, a succession with various lithologies (medium- and fine-grained sands, clays and clayey silts with carbonate intercalations) can be identified up to a depth of $45 \mathrm{~m}$.

Based on the information from the boreholes drilled, it was possible to design a scheme of the geological/geomorphological evolution of the upper Pleistocene-Holocene, which consists of four stages (Fig. 4). These stages show the evolution of a coastal area associated with transgressive or regressive processes that are characterized by sedimentation with strong lateral variations, both in thickness and in lithological composition.

Geologically, the system comprises:

- The upper Pleistocene (stages I and II). This includes "clayey silts with carbonate intercalations", and interfingering lenses or sheets of "very fine sand".

- The lower Holocene (stage III). This covers the coeval development of "medium sands" related to transgressive barriers and "grey clays with sandy intercalations" that 


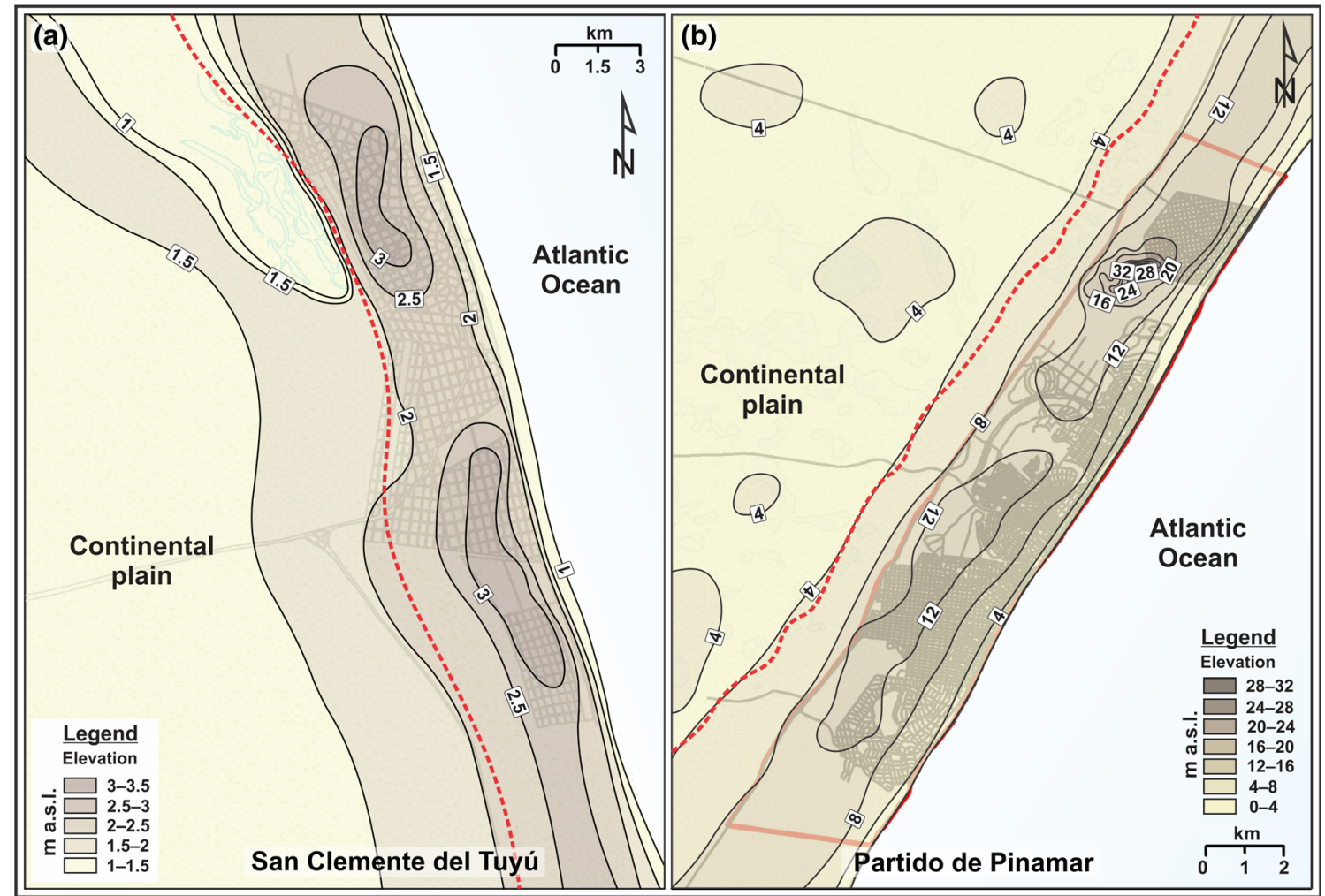

Fig. 2 Topographic maps: parts of the a northern sector, and $\mathbf{b}$ southern sector. The red dashed line indicates the approximate boundary between the continental plain and the sand-dune barrier

developed in a low-energy environment, which may only be restricted to the southern sector.
- $\quad$ The upper Holocene (stage IV). This is represented by the "fine sands" of the present-day sand-dune barrier.
Fig. 3 Type section and well logging for each sector under study (bgs below ground surface)

\begin{tabular}{|c|c|c|c|}
\hline \multirow{2}{*}{$\begin{array}{c}\text { Depth } \\
\text { (m bgs) }\end{array}$} & \multicolumn{2}{|c|}{ LITHOLOGICAL PROFILE } & \multirow{2}{*}{ WELL LOGGING } \\
\hline & $\begin{array}{c}\text { NORTHERN } \\
\text { SECTOR }\end{array}$ & $\begin{array}{l}\text { SOUTHERN } \\
\text { SECTOR }\end{array}$ & \\
\hline 0 & & & \\
\hline 5 & & & $\begin{array}{l}\text { - Fine and very fine sand, subrounded and well-sorted grain-size } \\
\text { distribution, light brown in colour } \\
\text { - Holocene shell fragments of various sizes } \\
\text { - Composition: quartz }(60 \%) \text {, mafic minerals }(20 \%) \text {, bioclasts }(20 \%)\end{array}$ \\
\hline 10 & & & \\
\hline & & & - Organic horizons. Fibrous, amorphous organic matter (40-60\%) \\
\hline 15 & $\vdots$ & & $\begin{array}{l}\text { - Greyish plastic clays with very well sorted, fine to very fine sand } \\
\text { intercalations (quartz) } \\
\text { - Slightly fragmented shell debris }\end{array}$ \\
\hline 25 & $\because$ & & $\begin{array}{l}\text { - Medium to fine dark grey sands with a very small percentage of } \\
\text { gravel material } \\
\text { - Variable proportions of highly fragmented shell debris } \\
\text { - Composition: quartz }(50 \%) \text {, mafic minerals }(35 \%) \text {, bioclasts }(15 \%)\end{array}$ \\
\hline 35 & 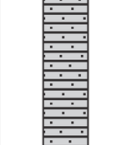 & $\%$ & $\begin{array}{l}\text { - Brown clayey silts with a carbonate matrix } \\
\text { - Clastic fraction }(30 \%) \text { composed of quartz and mafic minerals } \\
\text { - Layers of shell debris and coarse lithic components towards the } \\
\text { end of the sequence }\end{array}$ \\
\hline 40 & & $\%$ & $\begin{array}{l}\text { - Very fine dark sands to coarse silts with highly fragmented } \\
\text { shell debris } \\
\text { - Composition: quartz }(30 \%) \text {, mafic minerals }(60 \%) \text {, bioclasts }(10 \%)\end{array}$ \\
\hline 45 & & & \\
\hline
\end{tabular}



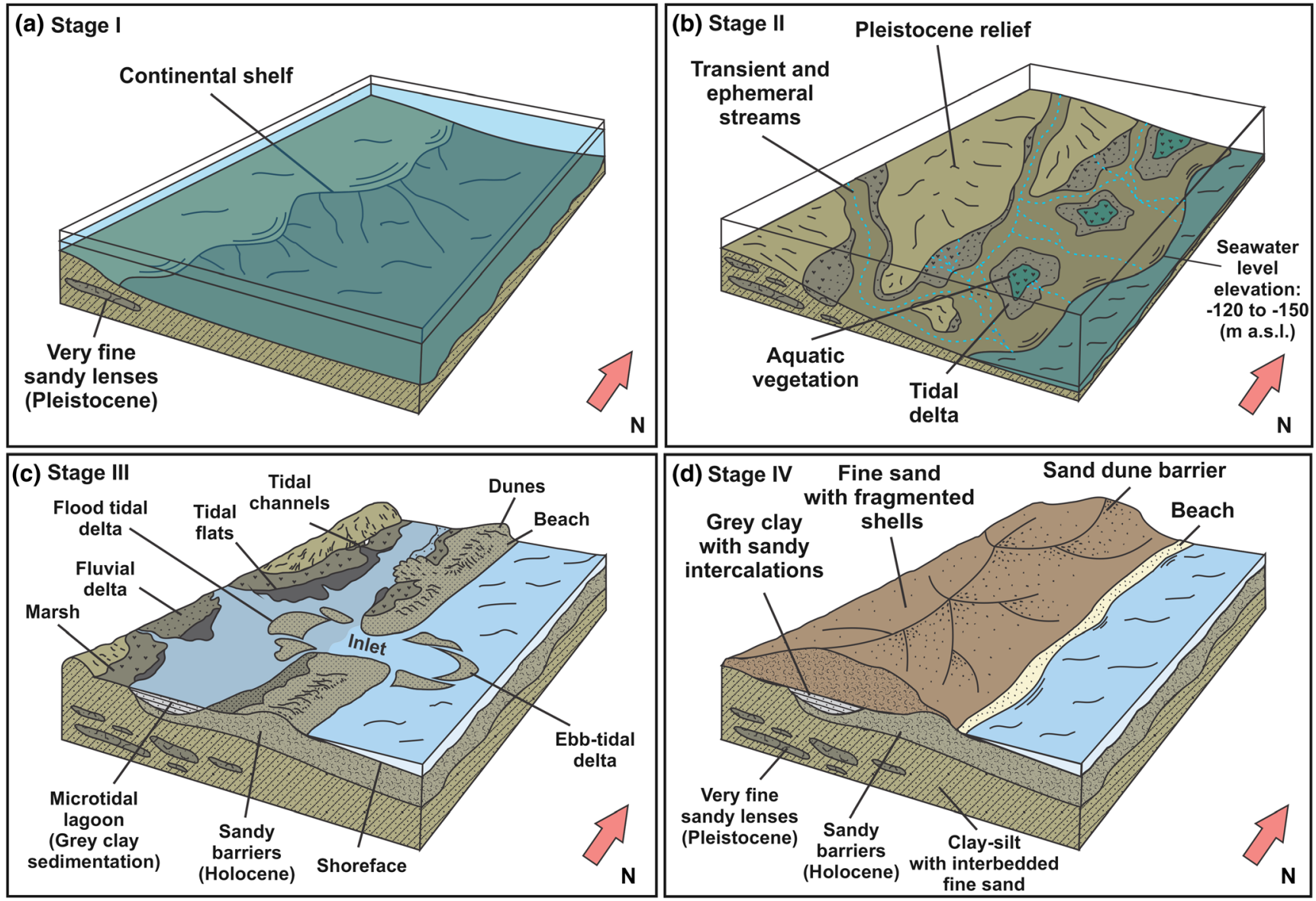

Fig. 4 Geological evolution scheme for the upper Pleistocene-Holocene. a-b the upper Pleistocene (stages $I$ and II), c the lower Holocene (stage III), and $\mathbf{d}$ the upper Holocene (stage IV)

The application of this scheme from a hydrogeological viewpoint makes it possible to recognize the following hydrofacies (Fig. 5):

- A (fine sand with shell fragments): aquifer containing the unsaturated zone and the water table. Thicknesses range between 2 and $15 \mathrm{~m}$. Average $T$ and $K$ values are 174 and $20 \mathrm{~m} / \mathrm{d}$ respectively, whereas $\mathrm{Sy}$ is 0.10 .

- B (grey clay with sandy intercalations + organic horizons): aquitard layer between hydrofacies $\mathrm{A}$ and $\mathrm{C}$, with maximum thicknesses of $12 \mathrm{~m}$. The values of $T_{v}$ and $K_{v}$ are $1 \times 10^{-5}$ and $1 \times 10^{-4} \mathrm{~m} / \mathrm{d}$, respectively.

- $\mathrm{C}$ (medium sands): aquifer layer with thicknesses reaching $12 \mathrm{~m}$ in the central sector. $T$ and $K$ range from 45 to 70 , and from 10 to $20 \mathrm{~m} / \mathrm{d}$, respectively, whereas Sy is $1 \times 10^{-3}$ to $1 \times 10^{-4}$.

- D (clayey silts with carbonate intercalations): aquitard layer between hydrofacies $\mathrm{C}$ and E, with $T_{v}$ and $K_{v}$ values of $1 \times 10^{-3}$ to $1 \times 10^{-4} 1 / \mathrm{d}$ and $1 \times 10^{-2}$ to $1 \times 10^{-3} \mathrm{~m} / \mathrm{d}$, respectively, and whose maximum thicknesses reach $40 \mathrm{~m}$.

- E (very fine sandy lenses): aquifer unit embedded as lenses up to $20 \mathrm{~m}$ thick within hydrofacies D. $T$ and $K$ values are from 15 to $150 \mathrm{~m}^{2} / \mathrm{d}$, and from 4 to $40 \mathrm{~m} / \mathrm{d}$, respectively, whereas Sy is in the $1 \times 10^{-3}$ to $1 \times 10^{-4}$ range.

This hydrogeological system is characterized by its hydraulic continuity, with a variety of connections between the aquifer layers, due to the presence and variations in thickness of the aquitard layers.

The results obtained for the northern sector and the southern sector make it possible to observe differences in the degree of expression and development of the lithological types in each case. From a practical point of view, these differences led to the development of two hydrogeological systems, which - although they occur in the same landform-show different behaviours.

In the northern sector (Partido de La Costa), the aquifer supplying the population is restricted exclusively to hydrofacies $\mathrm{A}$ and $\mathrm{C}$, whose combined thicknesses rarely exceed $12 \mathrm{~m}$. The hydrogeological basement in this area consists of a clayey complex that separates the freshwater from the brackish water that characterizes the deep aquifer system.

As regards the southern sector, the system comprises three aquifer layers. Hydrofacies $\mathrm{A}$ and $\mathrm{C}$ represent Holocene sedimentary cycles, whereas the genesis of hydrofacies $\mathrm{E}$ is upper 


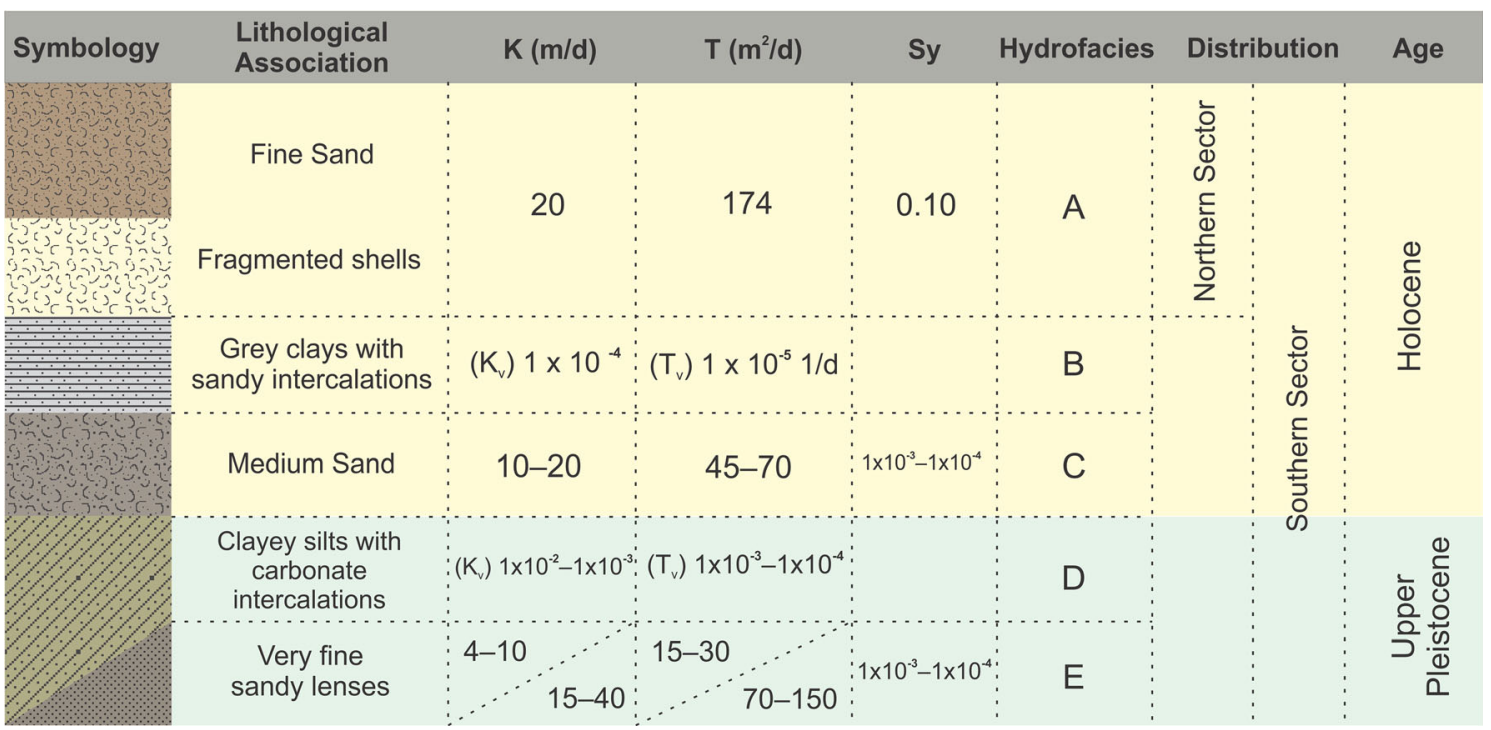

Fig. 5 Hydrogeological scheme

Pleistocene. These three aquifer layers are exploited simultaneously, constituting - depending on the occurrence and composition of the less permeable layers (aquitards) - a hydraulically interconnected system, whose useful thickness reaches at least $45 \mathrm{~m}$.

\section{Groundwater hydrodynamics and hydrochemistry}

In both sectors of the coastal barrier, the phreatic morphology is radial, with equipotential curves parallel to the coastline, which suggests one direction of groundwater flow towards the sea and another towards the continent (Fig. 6), with a hydraulic gradient that varies between 1.5 and $4 \mathrm{~km} / \mathrm{m}$. In general, the groundwater divide coincides with the greater topographic elevations, following an imaginary line oriented in a southwest-northeast direction. In the northern sector, the thickness of the aquifer ranges between 10 and $15 \mathrm{~m}$, with water table depths of less than $3 \mathrm{~m}$ below ground surface (b.g.s.). In the southern sector, the position of the water table is over $6 \mathrm{~m}$ b.g.s. in an aquifer with a thickness between 20 and $40 \mathrm{~m}$.

The water table is recharged naturally and in a direct manner by the infiltration of rainfall excess. The fluctuations in the water table throughout the year are caused by the distribution of the surpluses in the water balance, which become evident due to a generalized water table rise during the coldest months and a decrease during the warmest ones (Fig. 7).

Depending on the land use types, which include forests, urban area and sand dunes with scant or no vegetation, different infiltration conditions can be observed, conditions that are reflected in the configuration of the water table flow. In this sense, the largest surpluses occur in bare land $(470 \mathrm{~mm} /$ year $)$, with respect to forested land ( $261 \mathrm{~mm} /$ year), suggesting a higher evapotranspiration below tree cover. This phenomenon is especially important in the southern sector, owing to the extensive forested area.

The recharge of the units located at a greater depth in the southern sector occurs by vertical infiltration, indirectly from the water table, as suggested by the differences in hydraulic charge measured in the boreholes; this phenomenon is more evident in the topographically highest sectors. The hydrodynamic and hydrochemical behaviour of groundwater is conditioned by the geological/geomorphological evolution that occurred during the Quaternary.

From a hydrochemical point of view, water has a low salinity and is predominantly a calcium bicarbonate type. In the northern sector, the water evolution pattern can be observed in the direction of the flow, towards the west, in the transition towards the continental plain. This becomes evident in the passage from a sodium-calcium-bicarbonate type water to a sodium chloride type (Fig. 8). The occurrence of vertical chemical zonation has been observed, allowing the identification of units with low electrical conductivity groundwater $(<1,200 \mu \mathrm{S} / \mathrm{cm})$ up to a depth of 5-7 m, increasing below up to one order of magnitude $(12,000 \mu \mathrm{S} / \mathrm{cm})$. This phenomenon cannot be observed in the aquifer system in the southern sector, which results in a greater useful thickness of high quality water.

In the southern sector, the ion evolution shows the typical behaviour of recently infiltrated water whose flow direction is accompanied by an increase in ion concentrations, especially of $\mathrm{HCO}_{3}{ }^{-}, \mathrm{Na}^{+}$, and $\mathrm{Cl}^{-}$. Along the entire coastal barrier, groundwater has a pH below 8.3 and, therefore, there is no presence of $\left(\mathrm{CO}_{3}\right)^{2-}$ in the samples analyzed. There is a correlation between the topography and the hydrochemistry, as indicated by the occurrence of lower conductivity values in the topographically higher sectors that can be observed in Fig. 2.

The general isotopic composition of the northern sector ranges from -6.8 to $-4.3 \%$ o for $\delta^{18} \mathrm{O}$ and from -39 to $-21 \%$ o 


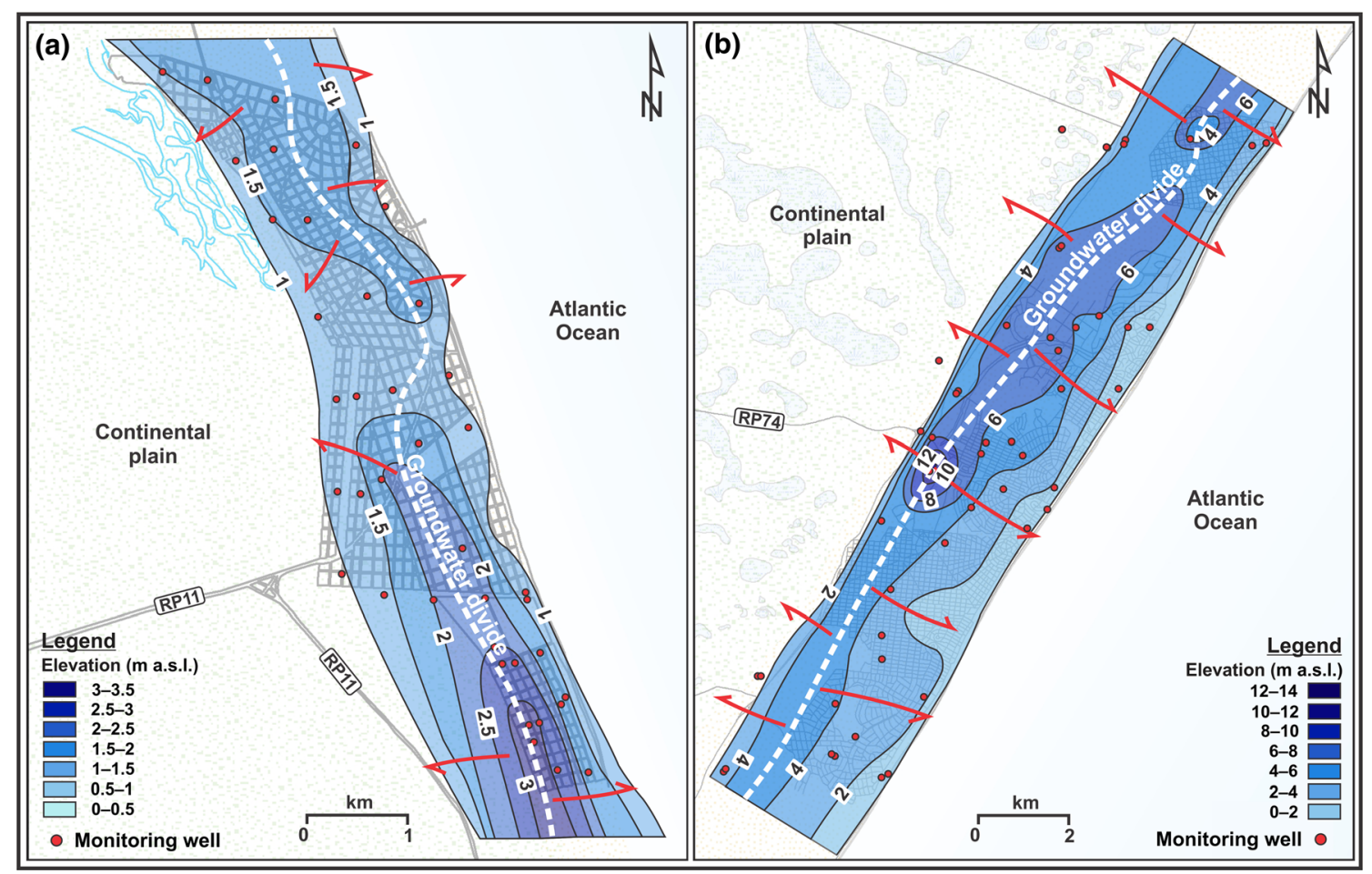

Fig. 6 Water-table contour maps for a San Clemente del Tuyú (Partido de La Costa) and b Partido de Pinamar

for $\delta^{2} \mathrm{H}$. In the southern sector, the variation ranges for $\delta^{18} \mathrm{O}$ are between -6.5 and $-2.6 \%$, whereas in the case of $\delta^{2} \mathrm{H}$, between -39 and $-15 \%$. The results indicate that rainwater rapidly infiltrates into the sandy substrate and reaches the water table almost without significant modification to its isotopic composition. Towards both edges of the barrier, the system maintains a delicate hydrochemical balance with predominantly brackish water (sulphate water) towards the west (continental plain) and salt water (chloride water) towards the east (South Atlantic Ocean; Fig. 8).

One of the problems occurring in both sectors (northern and southern) is related to the high concentrations of total $\mathrm{Fe}$ (up to $6.21 \mathrm{mg} / \mathrm{L}$ ) and $\mathrm{Mn}^{2+}$ (up to $1.25 \mathrm{mg} / \mathrm{L}$ ), whose origin is connected to the mineralogical composition of the sand constituting the groundwater reservoir. This condition brings about a series of inconveniences that are both sanitary, as they

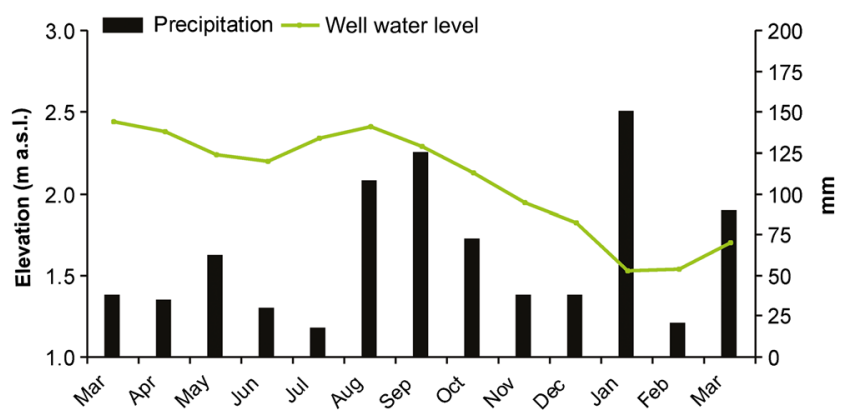

Fig. 7 Water-table fluctuation for a typical well and precipitation for a hydrological year limit the potability of drinking water, and infrastructural, due to the formation of incrustations in the water mains. Both situations entail a financial cost, either due to the need for equipment that would make it possible to decrease such concentrations, or to the maintenance of the supply system.

\section{Salinization process}

In coastal freshwater aquifers, it is necessary to consider the phenomenon of saltwater intrusion from the sea. In the area under study, this problem involves isolated water salinization processes caused by excessive exploitation. For instance, in the northern sector (Santa Teresita), a process of saltwater intrusion has been detected. In 1987, in the wells near the coast, the electrical conductivity values were $1,100 \mu \mathrm{S} / \mathrm{cm}$, whereas in 2012 , they were $12,000 \mu \mathrm{S} / \mathrm{cm}$. The sector affected by saltwater intrusion comprises $33 \%$ of the locality's waterfront. This problem could also be observed in the southern sector, in the localities of Pinamar, Valeria del Mar and Cariló. In this case, the intensive extraction of the resource caused the advance of the saltwater interface, which is made evident by the sudden rise in electrical conductivity values (from 1,000 to over $5,000 \mu \mathrm{S} / \mathrm{cm}$ ) in wells located on the coastline. Figure 9 shows an electrical conductivity profile of a well near the coastline in Pinamar. In the upper section, the profile displays values between 5,000 and $7,000 \mu \mathrm{S} / \mathrm{cm}$. Between 16 and $20 \mathrm{~m}$ b.g.s., an increase in electrical conductivity that reaches $19,000 \mu \mathrm{S} / \mathrm{cm}$ occurs; subsequently, values 


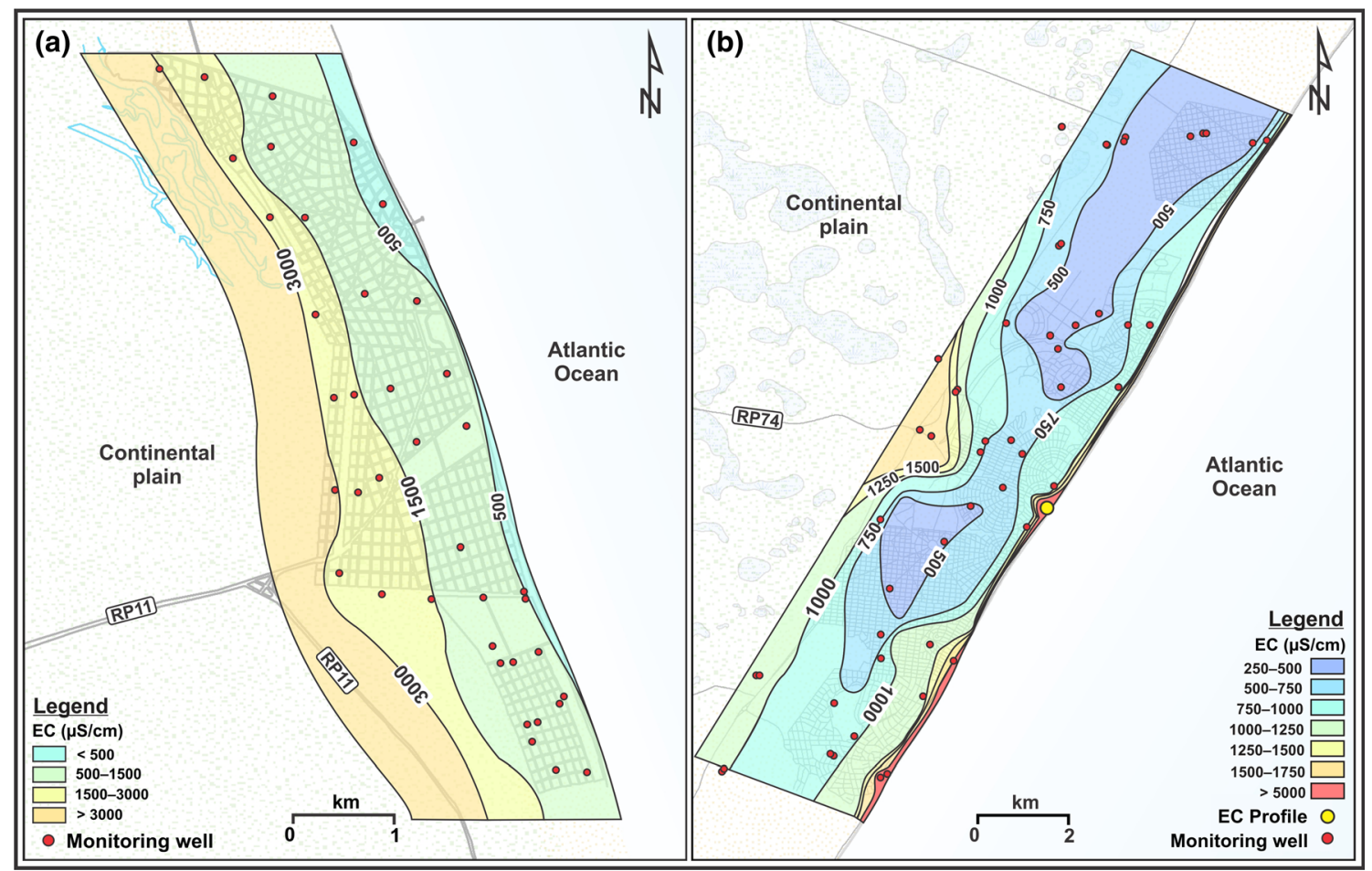

Fig. 8 Groundwater electrical conductivity (EC) map for a San Clemente del Tuyú (Partido de La Costa, northern sector) and b Partido de Pinamar (southern sector)

increase progressively, until they reach $35,000 \mu \mathrm{S} / \mathrm{cm}$ at $35 \mathrm{~m}$ b.g.s. The temporal analysis of the data series makes it possible to observe slight variations depending on the time of year, demonstrating the sensitive, dynamic relationship between fresh and salt water in that sector. The deepening of the groundwater levels and the salinization near the coast along time are connected to a larger number of inhabitants and, consequently, to higher water extraction for consumption.

\section{Urban developments}

The urban developments and the water available to meet the demands of the inhabitants occur in the physical medium described in the preceding. In the region, there is a trend towards the expansion of the urban areas, though no longer through the growth of the existing localities, but through independent real estate ventures; therefore, parallel to and associated with tourism, the proliferation of such ventures is one of the activities that have developed the most during the last five decades. The northern sector only has four real estate developments of the gated-community type occupying a limited area (Table 2). To the south of Punta Médanos, three other projects of greater extension and a larger offer of services are under construction. In these ventures, there are artificial lakes fed by the water table and, in many cases, used as reservoirs for the irrigation of common areas.

In the southern sector (Partido de Pinamar), there are numerous medium- and large-sized real estate ventures, the most relevant of which are shown in Table 2. This type of project also contemplates the creation of surface-water bodies, which must be fed permanently by means of the pumping from groundwater wells. The activities developed in the southern sector - when compared to the northern sector of the coastal barrier - are targeted at a limited social segment that, in general, has a higher purchasing power, as reflected in the statistics produced by the tourism board of the district.

In Punta Médanos, which according to the political boundary belongs to the Partido de La Costa (north), the natural characteristics are similar to those of the Partido de Pinamar (south). A higher availability of water resources has made it possible to lay out wooded landscapes and gardens demanding irrigation, as well as to feed artificial lakes, both for their ornamental value and for the development of water sports. The presence of a significant afforested area in these ventures (Fig. 10) suggests that this sector is not unlike the natural area in which the Partido de Pinamar develops, reinforcing the idea that geomorphology is the factor conditioning economic development.

\section{Urban water consumption and hydrogeological features}

The relationship between $T$ and Arev (Fig. 11a) makes it possible to recognize three groups of ventures. The first group comprises ventures $1-4$, which are located in the northern sector, with $T$ values below $200 \mathrm{~m}^{2} / \mathrm{d}$ and Arev values below $2 \mathrm{~km}^{2}$. The second group (8-15) is within the same range as 


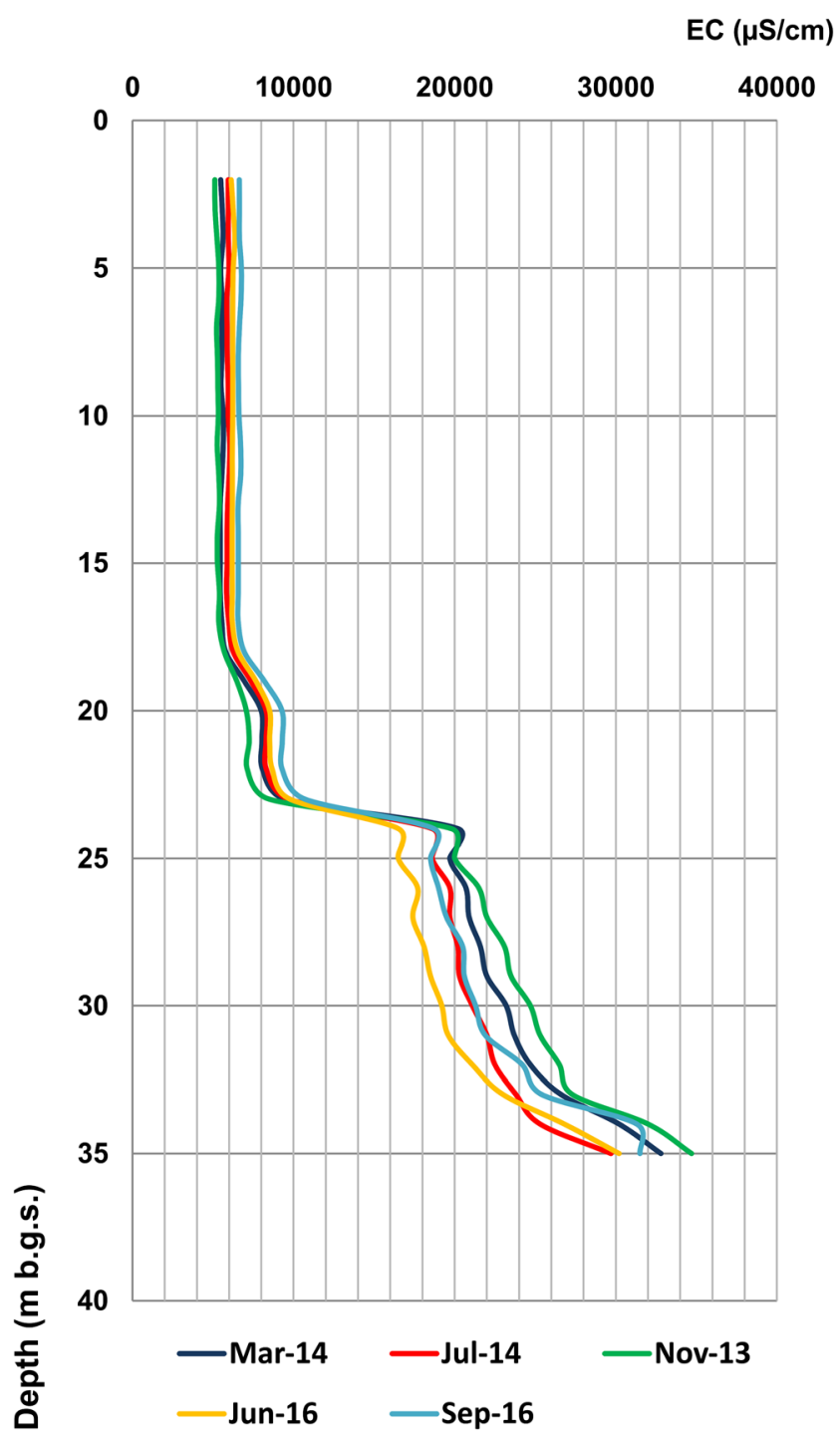

Fig. 9 Variation in electrical conductivity $(E C)$ at depth in the freshwater-saltwater interface area. The location of the well may be observed in Fig. 8 (yellow dot) regards the Arev values, but the $T$ values are between 200 and $300 \mathrm{~m}^{2} / \mathrm{d}$; this group is located in the southern sector. The third group is in the same sector as the previous group (Punta Médanos) and it consists of the ventures with the greatest Arev values (5, 6 and 7), between 6 and $10 \mathrm{~km}^{2}$. The distribution reflects the relationship between the possibilities for areal expansion and water availability in each sector. Therefore, in the northern sector, the smaller thicknesses (with low $T$ values) coincide with the ventures with small Arev values; whereas towards the southern sector, the thicknesses and $T$ values increase, allowing urban developments with a larger extension and a greater demand for water resources. A clarification should be made at this point regarding groups 2 and 3 since, according to the aforementioned definitions, both ventures should have a considerable area. The explanation for this situation lies in that the ventures in group 2 have only recently been established and have been laid out over the natural dune environment with no space restrictions, whereas ventures in group 3 had to adapt to the vacant spaces in the existing urban area of Pinamar.

The relationship between total water consumption (TWC) and Arev-the latter in its logarithmic representation for a greater distribution of the points (Fig. 11b) - shows that in most cases the daily consumption is below $1,000 \mathrm{~m}^{3}$, except for cases 6 and 7. The consumption calculated for venture 7with a volume larger than $10,000 \mathrm{~m}^{3} / \mathrm{d}$ - is striking, since in case 5 , which practically has the same area, such value is 28 times lower $\left(370 \mathrm{~m}^{3} / \mathrm{d}\right)$. The main difference lies in the planning and land use of each real estate venture; in the case of venture 7, the projection of inhabitants reaches 35,000 and it includes a golf course and an equestrian area, which entails a higher demand for irrigation water. On the other hand, venture 5 has fewer than 1,500 inhabitants. This architectural project has been oriented towards the conservation of larger sanddune sectors and of the natural environment.

Table 2 Real estate ventures by sector

\begin{tabular}{|c|c|c|c|c|c|}
\hline Sector & District & $\begin{array}{l}\text { Real estate } \\
\text { venture No. } \\
\text { (see Fig. } 10 \text { ) }\end{array}$ & $\begin{array}{l}\text { Real estate } \\
\text { venture area } \\
\left(\mathrm{km}^{2}\right)\end{array}$ & $\begin{array}{l}\Sigma \text { real estate } \\
\text { venture area } \\
\left(\mathrm{km}^{2}\right)\end{array}$ & $\begin{array}{l}\Sigma \text { real estate } \\
\text { venture area/ } \\
\text { district area }\end{array}$ \\
\hline Northern & Partido de La Costa (north) & $\begin{array}{l}1 \\
2 \\
3 \\
4\end{array}$ & $\begin{array}{l}0.92 \\
0.21 \\
1.34 \\
0.07\end{array}$ & 2.54 & 0.010 \\
\hline Southern & Partido de La Costa (south) & $\begin{array}{l}5 \\
6 \\
7\end{array}$ & $\begin{array}{r}9.96 \\
7.25 \\
10.11\end{array}$ & 27.33 & 0.110 \\
\hline & Partido de Pinamar & $\begin{array}{r}8 \\
9 \\
10 \\
11 \\
12 \\
13 \\
14 \\
15\end{array}$ & $\begin{array}{l}0.03 \\
0.06 \\
1.20 \\
0.05 \\
1.55 \\
0.22 \\
0.52 \\
0.10\end{array}$ & 3.73 & 0.056 \\
\hline
\end{tabular}


Fig. 10 Distribution of real estate ventures; the red dots represent the areas of the real estate ventures

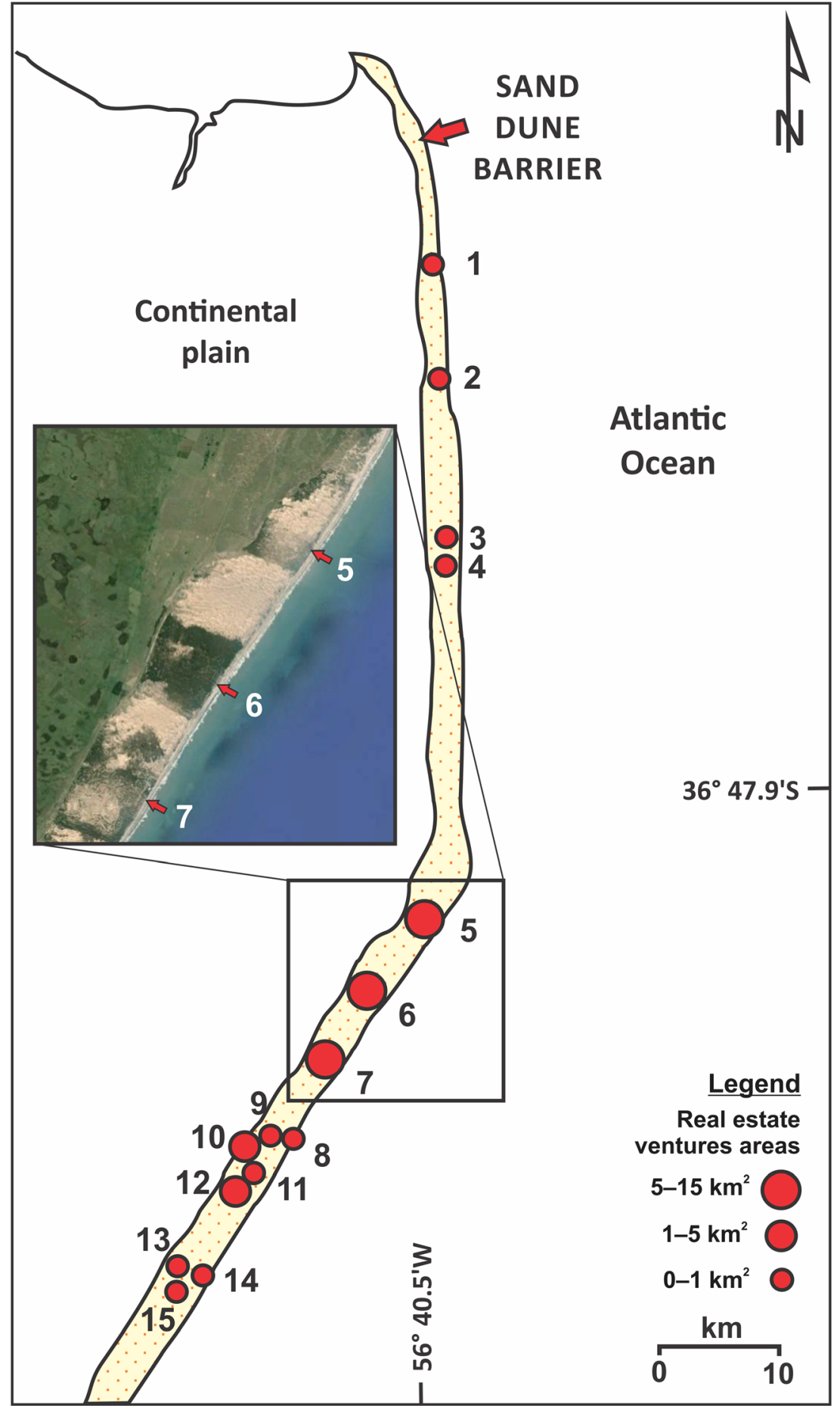

If the relationship of TWC vs Arev follows the trend line, it is interpreted as a region in which ventures have sustainable consumptions or the impact on the water cycle is acceptable. It could be established that, in general, ventures have a level of consumption consistent with the area covered. However, this is not the case of venture 7: when evaluating this relationship it can be observed that in the future it will lead to a situation in which the water resources will be greatly affected. The exploitable useful reserves may be compromised, and there is another possibility that should not be discarded: problems may arise associated with an inversion of the hydraulic gradient due to depression cones or an advance of the freshwatersaltwater interface.

The ventures identified with letters A and B correspond to those located in Malaysia, with Arev values below $0.10 \mathrm{~km}^{2}$, whereas those corresponding to Majorca (Spain) cover letters 
Fig. 11 a Transmissivity $(T)$ vs Area of real estate ventures (Arev), b Total water consumption (TWC) vs. Arev. The red dots indicate the ventures not located in Argentina
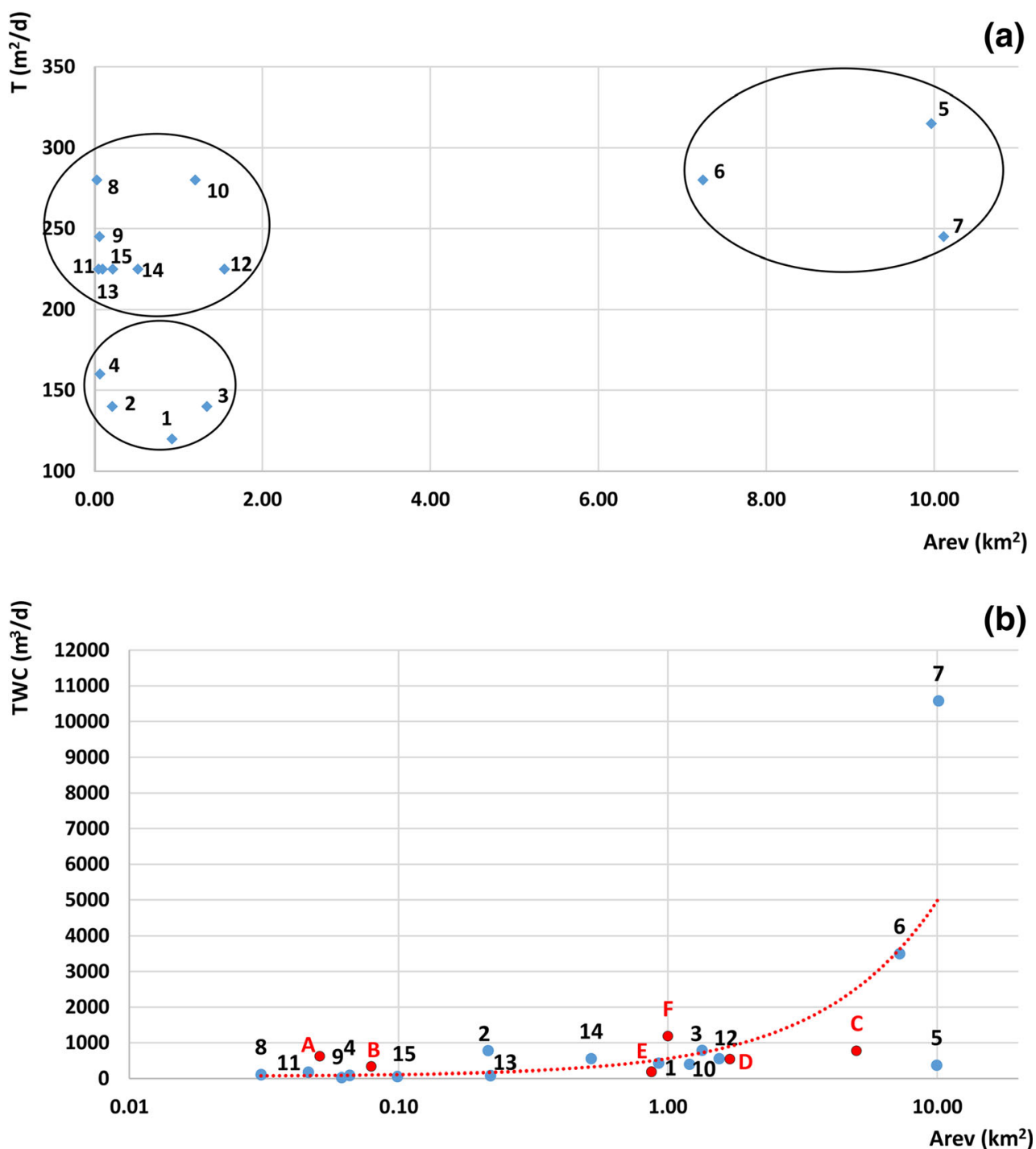

$\mathrm{C}$ to $\mathrm{F}$, with higher Arev values. These points follow the curve of the ventures analyzed, with TWC values below $1,000 \mathrm{~m}^{3}$. This would indicate that the relationship between Arev and TWC also holds for urban areas beyond the local area under study.

\section{Discussion}

The relationship between tourism and water consumption is a relatively unexplored topic and there are few detailed studies on the use of water resources for such purposes in different geographical environments (Gössling 2006, 2015; Gössling et al. 2012; Hadjikakou et al. 2013). Studies in the Mediterranean show that it is not the large hotels that are the highest consumers of water, but golf courses, private houses, and resorts with gardens and swimming pools (Rico-Amorosa et al. 2009); garden irrigation is the main source of consumption $(70 \%)$ of the water for recreational use in that European region (Hof and Schmitt 2011).

On the eastern coast of the Province of Buenos Aires, the relationship between the regional geomorphological evolution and the distribution of the groundwater resources can be recognized. In the two sectors analyzed, population growth stands out as a common indicator of socio-economic development. In turn, a similarity between the aquifer systems in the sand-dune barrier can be observed, as they share a similar geological history; however, there are differences between the northern and southern sectors that have an influence on the development of socio-economic activities.

The northern sector is characterized by a lower population density, with the tourist influx being composed of people with less purchasing power, less investment potential and shorter duration of stay during their leisure time. During the high tourist season, the population concentration reaches 10,000 inhabitants per $\mathrm{km}^{2}$. Real estate ventures are restricted, as 
the available freshwater resources are of a smaller magnitude and are mostly destined to supply the population, leaving no margin for the generation of lakes or for irrigation; besides, the coverage of the drinking water supply to the population is limited.

The differential geomorphological features in the northern sector are associated with a Holocene freshwater aquifer thickness that does not exceed $12 \mathrm{~m}$ and a water table occurring at about $3 \mathrm{~m}$ b.g.s or more. The regulating reserves available are of the order of $42 \mathrm{~mm} / \mathrm{km}^{2}$. The hydrogeological units are practically half as thick as the ones in the southern sector, and a vertical chemical zonation that decreases the availability of the freshwater reservoir can be observed.

As opposed to the facts described when discussing the northern sector, the southern sector (Partido de Pinamar) is characterized by a higher population density, and a more rapid progress can be recognized. During the summer months, a population concentration of 15,500 inhabitants per $\mathrm{km}^{2}$ is estimated. The profile of the tourist shows a high purchasing power, investing more in the region and holidaying for longer. The investments in real estate ventures associated with tourism are more significant. The drinking-water supply system has larger coverage and real estate ventures contemplate, apart from their own development, different amenities that imply greater water consumption (golf courses, spas, gardens, water parks, and polo fields). Besides, there has been an architectural trend in the last few decades towards the creation of artificial lakes that, even though their beds are impermeabilized, require a constant water supply in order to maintain their depth. In this sector, important real estate ventures can be found; for instance, the Partido de Pinamar has five water bodies covering an average surface of $4,200 \mathrm{~m}^{2}$, whereas Punta Médanos has four water bodies with an average surface of over $10,000 \mathrm{~m}^{2}$.

In the southern sector, the hydrogeological profile with available freshwater reaches a depth of 50 . The average position of the water table is shallower than $6 \mathrm{~m}$ b.g.s.; as a consequence of the thickness of the sand deposits (aquifer layers), the available freshwater reserves take on added importance, with the regulating reserves reaching a value of $77 \mathrm{~mm} / \mathrm{km}^{2}$ as a result. The natural dunes were modified by afforestation, which led to the alteration of the natural water balance, with the surpluses being reduced to almost half in the forested soil with respect to bare sandy soil. The occurrence of conifer forests is possible due to the presence of larger water reserves in this sector. "Environmental amenities" are factors that attract visitors to participate in outdoor recreational activities, with tree cover being one of them. The importance of tree cover for recreational purposes is widely recognized: it offers scenic views, privacy and aesthetically pleasing locations for such activities (Kuvan 2005; Van Berkel and Verburg 2012; Van Berkel et al. 2014)

\section{Conclusions}

The differences in the geomorphological evolution of the sand-dune barrier of the east coast of the Province of Buenos Aires condition the fresh groundwater reserves, which has direct consequences on the characteristics of the urban and territorial development. The comparison of the two sectors (northern and southern) shows contrasting indicators regarding tourism activity.

In the southern sector, the exploitable groundwater is associated with the upper Pleistocene and Holocene geomorphological evolution that generated three interrelated aquifer units, constituting a system whose useful thickness reaches at least $45 \mathrm{~m}$. On the other hand, the northern sector is restricted to two Holocene aquifer units whose thickness is approximately $12 \mathrm{~m}$.

Associated with the hydrogeological framework and freshwater availability, the southern sector differs from the northern sector in its higher population density and possibilities for investment in urban developments. This includes, apart from the afforestation with conifers in certain areas, the development of ventures with artificial lakes, golf courses and other infrastructure, which defines a type of tourism with a high purchasing power.

The relationship between $T$ and Arev reflects the possibilities for areal expansion and the availability of water in each sector. The lower $T$ values in the northern sector are associated with ventures with lower Arev and TWC, whereas in the southern sector, the higher $T$ values allow ventures with greater Arev and TWC.

The trend in the TWC vs Arev relationship is a basic indicator for the sustainable management of the water resources or for the identification of an acceptable impact on the water cycle. This relationship, confirmed by the comparison with urban areas in other locations (Spain and Malaysia) beyond the local context, may constitute a criterion to achieve a sustainable tourism industry, avoiding the risks of groundwater overexploitation and saltwater intrusion in coastal environments. The development of coastal real estate ventures associated with groundwater availability is conditioned by the negative impacts that may affect the groundwater reserves (saltwater intrusion, decrease in groundwater levels, nitrate contamination, among others). Studies of this kind are also necessary in the formulation of management and land use policies, in particular in those sectors in which the production of goods and services is limited to a single activity. Such is the case of high-quality or residential tourism developments, which entail a considerable water demand. The approach followed may be used by decision makers in other regions where coastal aquifers with similar characteristics occur, in order to assess the feasibility of future tourism projects based on the availability of water resources associated with geomorphological features. 
Acknowledgements The authors would like to thank the Cooperativa de Provisión de Obras y Servicios Públicos de San Clemente del Tuyú Lda for their collaboration in the fieldwork, the Secretaría de Planeamiento de Pinamar and the Secretaría de Turismo, Deportes y Cultura, Municipalidad de La Costa (Partido de La Costa District) for providing tourism statistics. This work was supported by the Consejo Nacional de Investigaciones Científicas y Técnicas (Nacional Council for Scientific and Technological Research) of Argentina, grant number PIP 0403, 2013-2015 and the Agencia Nacional de Promoción Científica y Tecnológica, grant number PICT 2013-2117, 2014-2017. The authors are thankful for the valuable comments of reviewers and editors, which improved the quality of the manuscript.

\section{References}

Allen RG, Pereira LS, Raes D, Martin Smith M (1998) Crop evapotranspiration: guidelines for computing crop water requirements. FAO Irrigation and Drainage Papers 56, FAO, Rome

Anderson MP (1989) Hydrogeological facies models to delineate largescale spatial trends in glacial and glaciofluvial sediments. Geol Soc Am Bull 101:501-511

ARBA (Agencia de Recaudación de la Provincia de Buenos Aires) (2015) CartoArba, visualizador de cartografía catastral [CartoArba, land register viewer]. http://www.arba.gov.ar/. Accessed 22 October 2015

Burke J, Moench M (2000) Groundwater and society: resources, tensions and opportunities. United Nations, New York

Carretero S, Kruse E (2012) Relationship between precipitation and water-table fluctuation in a coastal dune aquifer: northeastern coast of the Buenos Aires province, Argentina. Hydrogeol J 20:16131621

Carretero S, Kruse E (2014) Impacto de la urbanización en la infiltración en un área costera, Argentina [Impact of urbanization on infiltration in a coastal area, Argentina]. Tecnol Cienc Agua 6:5-24

Carretero S, Kruse E (2015) Iron and manganese content in groundwater on the northeastern coast of the Buenos Aires province, Argentina. Environ Earth Sci 73(5):1983-1995. doi:10.1007/s12665-014$3546-5$

Carretero S, Rapaglia J, Bokuniewicz H, Kruse E (2013a) Impact of sea level rise on saltwater intrusion length into the coastal aquifer, Partido de La Costa, Argentina. Cont Shelf Res 61-62:62-70

Carretero S, Dapeña C, Kruse E (2013b) Hydrogeochemical and isotopic characterisation of groundwater in a sand-dune phreatic aquifer on the northeastern coast of the province of Buenos Aires. Isot Environ Health Stud 49(3):399-419

Carretero S, Braga F, Kruse E, Tosi L (2014) Temporal analysis of the changes in the sand-dune barrier in the Buenos Aires Province, Argentina, and their relationship with the water resources. Appl Geogr 54:169-181

Cavallotto JL (2002) Evolución Holocena de la llanura costera del margen sur del Río de la Plata [Holocene evolution of the coastal plain on the southern bank of the Río de la Plata]. Rev Asoc Geol Argent 57(4):376-388

Custodio E (2010) Coastal aquifers of Europe: an overview. Hydrogeol J $18: 269-280$

da Cunha Rebouças A (1999) Groundwater resources in South America. Episodes 223:232-237

Domene E, Saurí D (2006) Urbanisation and water consumption: influencing factors in the metropolitan region of Barcelona. Urban Stud 43(9):1605-1623

Durán Valsero JJ, Fernández ML, Mateos Ruiz RM, Robledo Ardila PA (2001) Las aguas subterráneas y los campos de golf, una aproximación integradora [Groundwater and golf courses, an integrated approach]. In: Pulido Leboeuf PA, Pulido Bosch A, Vallejos Izquierdo A (eds) V Simposio sobre el Agua en Andalucía, vol 2. Almeria, Spain, 25-28 September 2001, pp 61-68

El Mrini A, Maanan M, Anthony EJ, Taaouati M (2012a) An integrated approach to characterize the interaction between coastal morphodynamics, geomorphological setting and human interventions on the Mediterranean beaches of northwestern Morocco. Appl Geogr 35:334-344

El Mrini A, Anthony E, Maanan M, Taaouati M, Nachite M (2012b) Beach dune degradation in a Mediterranean context of strong development pressures, and the missing integrated management perspective. Ocean Coast Manag 69:299-306

Gössling S (2006) Tourism and water. In: Gössling S, Hall CM (eds) Tourism, global environmental change. Routledge, London

Gössling S (2015) New performance indicators for water management in tourism. Tour Manag 46:233-244

Gössling S, Peeters P, Hall M, Ceron J-P, Dubois G, La Vergne L, Scott D (2012) Tourism and water use: supply, demand, and security - an international review. Tour Manag 33:1-15

Hadjikakou M, Chenoweth J, Miller G (2013) Estimating the direct and indirect water use of tourism in the eastern Mediterranean. J Environ Manag 114:548-556

Hantush MS, Jacob CE (1955) Non-steady radial flow in an infinite leaky aquifer. Trans Am Geophys Union 36(1):95-100

Hof A, Schmitt T (2011) Urban and tourist land use patterns and water consumption: evidence from Mallorca, Balearic Islands. Land Use Policy 28:792-804

INDEC, Instituto Nacional de Estadística y Censos de la República Argentina (2010) Censo Nacional de Población, Hogares y Viviendas, Buenos Aires [National Census of Population, Homes and Housing, Buenos Aires]. http://www.indec.gov.ar. Accessed 15 July 2015

Kent M, Newnham R, Essex S (2002) Tourism and sustainable water supply in Mallorca: a geographical analysis. Appl Geogr 22:351374

Koerth J, Vafeidis A, Carretero S, Sterr H, Hinkel J (2014) A typology of household-level adaptation to coastal flooding and its spatio-temporal patterns. Springerplus 3:466. doi:10.1186/2193-1801-3-466

Kuvan Y (2005) The use of forests for the purpose of tourism: the case of Belek Tourism Center in Turkey. J Environ Manag 75:263-274

Lyman GT (2012) How much water does golf use and where does it come from? Environmental Programs, United States Golf Association Golf's Use of Water: Challenges and Opportunities, A USGA Summit on Golf Course Water Use, Dallas, TX, November 2012. http://usgatero.msu.edu/v11/216335.pdf. Accessed 8 October 2015

Marcomini S, López R (2010) Erosión y manejo costero en Las Toninas, Partido de La Costa, Provincia de Buenos Aires [Erosion and coastal management in Las Toninas, Partido de La Costa, Province of Buenos Aires]. Rev Asoc Geol Argent 66(4):490-498

Monserrat AL (2010) Evaluación del estado de conservación de dunas costeras: dos escalas de análisis de la costa pampeana [Evaluation of the coastal dunes conditions: two analysis scales of the pampean coast]. Facultad de Ciencias Exactas y Naturales, Universidad de Buenos Aires. http://digital.bl.fcen.uba.ar/gsdl-282/cgi-bin/library.cgi?a=d\&c= tesis\&d=Tesis_4715_Monserrat. Accessed 23 October 2015

Monserrat AL, Bonardi MC (2012) Clasificación de las dunas costeras pampeanas según su tipo de cobertura [Classification of the Pampean coastal dunes according to the type of cover]. Rev Iberoamericana Investig Desarrollo Edu. http://cenid.org.mx/ memorias/ciba/index.php/CIBA/article/view/4/4. Accessed 23 October 2015

Montanari A, Young G, Savenije HHG, Hughes D, Wagener T, Ren LL, Koutsoyiannis D, Cudennec C, Toth E, Grimaldi S, Blöschl G, Sivapalan M, Beven K, Gupta H, Hipsey M, Schaefli B, Arheimer B, Boegh E, Schymanski SJ, Di Baldassarre G, Yu B, Hubert P, Huang Y, Schumann A, Post DA, Srinivasan V, Harman C, 
Thompson S, Rogger M, Viglione A, McMillan H, Characklis G, Pang Z, Belyaev V (2013) "Panta Rhei: everything flows" - change in hydrology and society - the IAHS scientific decade 2013-2022. Hydrol Sci J 58(6):1256-1275. doi:10.1080/02626667.2013. 809088

Neuman SP (1975) Effect of partial penetration on flow in unconfined aquifers considering delayed gravity response. Water Resour Res 10(2):303-312

Parker G (1991) Caracterización geológica y geomorfológica del sector Punta Médanos-Pinamar: informe preliminar. Provincia de Buenos Aires [Geological and geomorphological characterization of the Punta Médanos-Pinamar sector: preliminary report. Province of Buenos Aires]. 44 pp

Parker G, Violante RA (1989) Geología y Geomorfología: regiones I y II. Convenio Consejo Federal de Inversiones y Servicio de Hidrografía Naval, Informe final [Geology and geomorphology: regions I and II. Agreement between the Federal Investment Council and the Naval Hydrographic Service, final report]. Punta Rasa-Faro Querandí. Province of Buenos Aires, $141 \mathrm{pp}$

Planas AC, Gaviño Novillo M, Mendiburo N, Calcagno A, Urbano Jáuregui L (2000) Informe sobre la gestión del agua en la República Argentina [Water management report in Argentina]. JVP, Buenos Aires

Re V (2015) Incorporating the social dimension into hydrogeochemical investigations for rural development: the Bir Al-Nas approach for socio-hydrogeology. Hydrogeol J 23:1293-1304. doi:10.1007/ s10040-015-1284-8

Rico-Amorosa A, Olcina-Cantosa M, Jorge Sauri D (2009) Tourist land use patterns and water demand: evidence from the Western Mediterranean. Land Use Policy 26:493-501

Rodrigues Capítulo L (2015) Evaluación geohidrológica en la región costera oriental de la provincia de Buenos Aires: caso de estudio Pinamar [Hydrogeological evaluation in the eastern coast of the Province of Buenos Aires: case of study Pinamar]. PhD Thesis, Facultad de Ciencias Naturales y Museo, La Plata, Argentina

Rodrigues Capítulo L, Kruse E (2011) Balance hidrológico en un área costera medanosa con forestación: caso de estudio-Partido de Pinamar, Provincia de Buenos Aires [Water balance in a sand- dune coastal area with forestation: case of study-Partido de Pinamar, Province of Buenos Aires]. In: García RF, Rocha Fasola MV (eds) VII Congreso Argentino de Hidrogeología y V Seminario Hispano-Latinoamericano Sobre Temas Actuales de la Hidrología Subterránea, Hidrogeología Regional y Exploración Hidrogeológica Buenos Aires. Asociación Civil Grupo Argentino de la Asociación Internacional de Hidrogeólogos, Buenos Aires, pp 80-87

Secretaría de Turismo, Cultura y Educación, Municipalidad de Pinamar (2015) Encuesta Enero-Febrero 2014, Buenos Aires, Pinamar [January-February survey 2014, Buenos Aires Pinamar]. http:// www.repotur.gov.ar/handle/123456789/3875. Accessed 15 October 2015

Secretaría de Turismo, Deportes y Cultura, Municipalidad de La Costa (Tourism, Sports and Culture, Municipality of La Costa) (2015) Encuesta de afluencia turística: perfiles del visitante, consumo y valuación del destino turístico, Partido de La Costa, Buenos Aires [Tourism Survey: visitor profile, consumption and tourist destination evaluation. Partido de La Costa, Buenos Aires]. http://acosta. tur.ar/tlc/estadisticas/encuesta-afluencia-turistica. Accessed October 2015

Tang F (2012) A study of water consumption in two Malaysian resorts. Int J Environ Chem Ecol Geol Geophys Eng 6(8):506-511

Theis CV (1935) The relation between the lowering of the piezometric surface and the rate and duration of discharge of a well using ground-water storage. Trans Am Geophys Union 16(2):519-524

Thornthwaite C, Mather J (1955) The water balance. Climatol 8:1-37

Van Berkel DB, Verburg PH (2012) Spatial quantification and valuation of cultural ecosystem services in an agricultural landscape. Ecol Indic 275:641-658

Van Berkel DB, Munroe DK, Gallemore C (2014) Spatial analysis of land suitability, hot-tub cabins and forest tourism in Appalachian Ohio. Appl Geogr 54:139-148

Violante RA, Parker G, Cavallotto JL (2001) Evolución de las llanuras costeras del este bonaerense entre bahía Samborombón y la laguna Mar Chiquita durante el Holoceno [Evolution of the coastal plains of eastern Buenos Aires between Samborombón Bay and Mar Chiquita Lake during the Holocene]. Rev Asoc Geol Argent 56(1):51-66 